\title{
Bracing the wind and riding the norm life cycle: inclusive peacebuilding in the European capacity building mission in Sahel-Mali (EUCAP Sahel-Mali)
}

\section{Shyamika Jayasundara-Smits}

To cite this article: Shyamika Jayasundara-Smits (2018) Bracing the wind and riding the norm life cycle: inclusive peacebuilding in the European capacity building mission in Sahel-Mali (EUCAP Sahel-Mali), Peacebuilding, 6:3, 233-247, DOI: 10.1080/21647259.2018.1491683

To link to this article: https://doi.org/10.1080/21647259.2018.1491683

(c) 2018 The Author(s). Published by Informa UK Limited, trading as Taylor \& Francis Group

曲 Published online: 13 Jul 2018.

Submit your article to this journal $\widetilde{ }$

Џ Article views: 192

View Crossmark data $\widetilde{ }$ 


\title{
Bracing the wind and riding the norm life cycle: inclusive peacebuilding in the European capacity building mission in Sahel-Mali (EUCAP Sahel-Mali)
}

\author{
Shyamika Jayasundara-Smits (1D
}

International Institute of Social Studies, Erasmus University Rotterdam, The Hague, The Netherlands

\begin{abstract}
Since the political crisis in 2012, the European Union has stepped up its commitment to Mali and the Sahel using various external intervention instruments gathered under the Common Security and Defence Policy (CSDP). These instruments are designed to achieve functional and normative goals of the EU. Situating in the debate on normative actorness of the EU and by applying the Whole-of-Society (WOS) approach to conflict prevention and peacebuilding, this paper investigates how the European Capacity Building mission for the Malian Security Forces (EUCAP Sahel-Mali) is operationalising two key EUSSR-related norms - local ownership and inclusivity- and manoeuvres context and programme specific challenges. By analysing the missiontraining/capacity building and outreach, this paper argues the EUCAP mission has been largely functional than normative driven, thus reducing the EU's overall reputation as a normative actor, particularly in the area of security. This paper offers practical recommendations to reach the EU's normative goals via SSR.
\end{abstract}

\section{ARTICLE HISTORY}

Received 18 May 2018

Accepted 19 June 2018

\section{KEYWORDS}

European Union; Norms; Security Sector Reform; Mali; EUCAP Sahel

\section{Introduction}

Situated in the ongoing debates on norms ${ }^{1}$ in international politics and external intervention, this paper investigates the EU's normative actorness, ${ }^{2}$ in the fields of conflict prevention and peacebuilding, and in particular, the contribution to Security Sector Reform (SSR) as a discreet field of normative action. ${ }^{3}$ With the

CONTACT Shyamika Jayasundara-Smits jayasundara@iss.nl $\Theta$ International Institute of Social Studies, Erasmus University Rotterdam, The Hague, The Netherlands

${ }^{1}$ Norms are defined as ideas of varying degrees of abstraction and specification with respect to fundamental values, organising principles or standardised procedures that resonate across many states and global actors, having gained support in multiple forums including official policies, laws, treaties or agreements. Norms are also understood as standards of behaviour based on inter-subjective validity. L.Zimmerman, Global Norms with a Local Face: Rule-of-Law Promotion and Norm Translation (Cambridge: Cambridge University press 2017):7.

${ }^{2}$ H.Bull,'Civilian Power Europe: A Contradiction in Terms?'. JCMS: Journal of Common Market Studies, 21, no2 (1982):149-170; I. Manners, ' Normative Power Europe: A Contradiction in Terms?'. JCMS: Journal of Common Market Studies, 40 (2002): $235-258$.

${ }^{3}$ E.Gordon, A.C.Welch and E.Roos, 'Security Sector Reform and the Paradoxical Tension between Local Ownership and Gender Equality'. Stability: International Journal of Security and Development, 4, no.1), (2015):53. T. A. Donais, ' Inclusion or Exclusion? Local Ownership and Security Sector Reform', Studies in Social Justice', 3, no. 1 (2009): 117-131. A.J.Bellamy, 'Security Sector Reform: Prospects and Problems', Peace, Security \& Global Change (formerly Pacifica Review) 15, no.2 (2003): 101-119. P. Jackson, 'Security Sector Reform and State Building', Third World Quarterly 32, no.10 (2011): 1803-1822. R.Kunz, 'Gender and Security Sector Reform: Gendering Differently?', International Peacekeeping 21, no.5(2014): 604-622. M.Sedra, 'The HollowingOut of the Liberal Peace Project in Afghanistan: The Case of Security Sector Reform', Central Asian Survey 32, no.3(2013): 371-387. 
return of realpolitik and the realist security dilemma in international politics and the move by the EU to define its overall approach to security and foreign affairs based on 'principled-pragmatism', 4 the EU has come under increased critical scrutiny regarding the delivery of its normative commitments.

Despite the commitment to combine principles/norms with pragmatism, scholars observe that pragmatism is increasingly taking precedence over principles and norms. ${ }^{5}$ In the case of SSR, the imbalance between the functional and normative imperative of EU actions can be partly explained owing to the contextually rooted challenges met by SSR missions in third countries. However, a more robust inquiry based on a flexible yet analytically rich framework is needed to capture the other challenges experienced by the EU, especially the ones that are programme specific and the challenges emanating from a process of dynamic interactions between the context and programme goals.

\section{Whole-of-Society approach (WOS) ${ }^{6}$}

The paper uses the 'Whole-of-Society' (WOS) approach to conflict prevention and peacebuilding to propose that the EU could enhance the normative dimension of its SSR interventions, compared to the principled pragmatism approach, through a clearer focus on the normative standards such as inclusivity, ownership and gender equality, which are implied but which appear to have been eclipsed or relegated in recent examples of SSR missions such as EUCAP Sahel.

The WOS approach is both a prescriptive and a normative ideal. As a prescriptive approach, 'WOS' assumes that peacebuilding and conflict prevention will be more effective when a broad(er) range of actions and intentions are identified and taken into account. As a normative approach, WOS emphasises the importance of inclusivity as a key principle of external interventions. In this sense, the term 'WOS' refers to ambitions which underpinned and motivated the Mali SSR intervention. The paper seeks to critically assess the range of actors with which the EU engaged and identify related issues of exclusion and marginalisation as part of the engagement process. By focusing on presences-absences, inclusions-exclusions and the marginalisation-elevation of certain actors over the others, we hope to show the opportunities for enhancing these normative aspects of the EUCAP Sahel-Mali mission, as well as the implications for not so doing.

In this paper, we refer to 'inclusivity' to denote both actors and spaces in a conflict environment. It refers to the degree of access to meaningful participation and decision-making by a range of actors concerned with/affected by a given conflict, beyond the most powerful elites. These actors can vary from communitybased organisations to ordinary citizens to the potential spoilers, who can exercise

\footnotetext{
${ }^{4}$ EU External Action Service (EEAS GSFSP), 'Shared Vision, Common Action: A Stronger Europe - A Global Strategy for the European Union's Foreign and Security Policy'. Brussels (2016)..

${ }^{5}$ S.Biscop, 'The EU Global Strategy: Realpolitik with European Characteristics' in Might and Right in World Politics, International Security: a European - South American Dialogue 2016, Konrad-Adenauer-Stiftung, Rio de Janeiro (2016).

${ }^{6}$ This section of the article is built on M.Martin, V.Bojicic-Dzelilovic, C. van der Borgh and G. Frerks' WOSCAP theoretical and Methodological Framework', London School of Economics and Political Science, Utrecht University (2015).
} 
meaningful voice and agency in the design and the implementation of SSR. ${ }^{7}$ We assume being inclusive will minimise resistance and rejection from the often marginalised yet vocal/hardliner actors and increase legitimacy and responsibility of the programme and of its outcomes from a wide range of constituencies with the ability to exercise voice and protect their interests throughout the reform process. Overall, by applying the WOS approach to the EUCAP Sahel mission we hope to show how the EU could identify and address some of the challenges related to norm operationalising, diffusion and internalisation via SSR both at vertical and horizontal levels. In the WOS framework, vertical axis represents an actor perspective with a focus on normative and practical/operational challenges to improve inclusivity and engage a wide range of actors in peacebuilding interventions. The horizontal axis comprises multiple actions located in different fields of practice and policy. ${ }^{8}$ By doing so, we hope to highlight some problem-solving possibilities within the mission and offer suggestions how a WOS approach could assist the EU to adapt and reform SSR practices in the future.

In the following section, we present the normative trajectory of the EU-SSR, then the key objectives of the EUCAP Sahel-Mali mission, highlighting the functional and the normative agendas underpinning them. Next, the paper analyses how key SSR norms- local ownership and inclusivity (including gender) have been operationalised in the EUCAP Sahel mission and the challenges in doing so. In the concluding section, the paper offers practical suggestions on what the EU could do to overcome some of the challenges identified for norm realisation, through applying a WOS perspective.

\section{The normative trajectory of the EU-SSR}

SSR is an indispensable element of the EU's combined approach to state building, conflict prevention and peacebuilding. Drawing from the OECD definition ${ }^{9}$ the EU defines SSR as

the process of transforming a country's security system, so that it gradually provides individuals and the state with more effective and accountable security in a manner consistent with respect for human rights, democracy, the rule of law and the principles of good governance. SSR is a long-term and political process, as it goes to the heart of power relations in a country. It needs to be nationally driven and requires political commitment and leadership, inter-institutional cooperation and broad stakeholder participation to achieve the widest possible consensus.

Although a clear definition of SSR is a relatively recent development in EU policy, since the early 1990s, the EU has undertaken many SSR-related activities. ${ }^{10}$ The present form and the content of EU-SSR is the outcome of a complex

\footnotetext{
${ }^{7}$ T.Donais and E.McCandless,' International Peace Building and the Emerging Inclusivity Norm', Third World Quarterly, 38, no.2 (2017):293.

${ }^{8}$ Refer to the introductory article of this volume for an elaborate discussion of these two axes.

${ }^{9}$ OECD. The OECD DAC Handbook on Security System Reform: supporting security and justice OECD, Paris, at: www. oecd.org/dataoecd/43/25/38406485.pdf. (2007):5.

${ }^{10} \mathrm{~F}$. Longo, 'Externalization of the Internal Security Strategy in the Framework of Multilateralism: The Case of Security Sector Reform', in New Challenges for the EU Internal Security Strategy, eds. Maria O'Neill, Ken Swinton, Aaron Winter (Cambridge Scholars Publishing, (2013):244.
} 
interplay between various norms, ideas, interests and the contestation and negotiation between knowledge and power among the above mentioned three epistemic communities. ${ }^{11}$ Since the Feira Council meeting (2000) that established SSR as an important goal of the EU's external policy, SSR is being regularly featured as one of EU's flagship programme. In the backdrop of changing geo-strategic relations and the looming 'conventional security dilemma', ${ }^{12}$ today SSR has even become a strategic priority. ${ }^{13}$ Furthermore, SSR can be regarded as a testing ground and a measure of EU's normative actorness. However, both the normative and functional achievements of the EU-SSR are not without criticisms. One main and recurrent criticism is SSR being the linchpin of EU's liberal state building and peacebuilding project. ${ }^{14}$ For the EU, SSR is very much a technical as well as a political process. While the technical underscores the functional imperative, the political underscores the normative ${ }^{15}$ Thus, via SSR, the EU strives to assist third countries to be effective in their security provisioning by balancing the state's monopoly of violence and monopoly of legitimacy. ${ }^{16}$ Monopoly of legitimacy is primarily sought by applying a plethora of liberal normative principles: human rights, democracy, and rule of law, good governance, local ownership, human security, inclusivity and gender equality.

Since its origins, the EU has been perceived as a norm entrepreneur/inventor and diffuser, ${ }^{17}$ due to its explicit normative commitments. ${ }^{18}$ The EU's normative actorness hinges on its ability to effectively and sustainably diffuse as well as help internalise EU's norms through interventions in a third country, and in this respect the EU has struggled sometimes due to zero-adoption, selective adoption and resistance it has encountered. Moreover the EU's track record of

\footnotetext{
${ }^{11} \mathrm{G}$. Faleg, 'Between Knowledge and Power: Epistemic Communities and the Emergence of Security Sector Reform in the EU Security Architecture', European Security, 21, no2, (2012):167. Epistemic community as a network of professionals from a variety of disciplines and backgrounds, who share a common set of normative and principled beliefs which guide their social actions, having a shared causal beliefs based on their analysis of practices and a shared notions of validity characterised by intersubjective, internally defined criteria for weighing and validating knowledge and a common policy enterprise. P.M.Haas, Introduction: Epistemic Communities and International Policy Coordination', International Organization, Knowledge, Power, and International Policy Coordination, 46, no. 1 (19,920):3.

${ }^{12}$ Refers to a situation in which actions taken by a state to increase its own security (usually by military means) cause reactions from other states, which in turn lead to a decrease rather than an increase in the original state's security in J.Herz, Political Realism and Political Idealism: A Study in Theories and Realities, (Chicago: University of Chicago Press 1951).

${ }^{13}$ The EU Global Strategy - Year 1 at: https://europa.eu/globalstrategy/en/vision-action.

${ }^{14}$ T. A. Donais, 'Empowerment or Imposition? Dilemmas of Local Ownership in Post-Conflict Peacebuilding Processes', Peace \& Change, 34, no. 1 (2009):6.

${ }^{15}$ Here, the functional imperative refers to the ability to deploy force against external threats, efficiently and effectively. In other words 'get the job done'. The normative imperative which is also understood as societal imperative. This is equivalent to soft power. In the case of EU-SSR, this is derived from the European Liberal values and institutions. In previous research the scholars have explored the tension between these two imperatives, where optimising functional imperative is affected by normative imperative. S.Jayasundara-Smits, 'Civil-Military Synergy at Operational Level in EU External Action', Global Partnership for the Prevention of Armed Conflict (GPPAC), The Hague (2016):8.

${ }^{16}$ S.Jayasundara-Smits and L.Schirch, 'EU and Security Sector Reform: Tilting at Windmills?' WOSCAP-EU, Global Partnership for the Prevention of Armed Conflict (GPPAC), The Hague (2015):3.

${ }^{17}$ See L.Zimmermann, 'Same, Same or Different? Norm Diffusion Between Resistance, Compliance, and Localization in Post-conflict States', International Studies Perspectives, 1-19 (2014):100.

This distinction of stages is derived from the 'norm life-cycle' model of Finnemore and Sikkink 1998. In the norm diffusion literature, specific local context in which a norms are promoted and the different outcomes of norm diffusion: resistance, full adoption, or a decoupling of rules and practices is captured.

${ }^{18}$ K.Vadura,'The EU as 'Norm Entrepreneur' in the Asian Region: Exploring the Digital Diplomacy Aspect of the Human Rights Toolbox', Asia Europe Journal, 13, no.3, (2015):349-360.
} 
implementing and realising these norms in a third country via SSR is rather poor. ${ }^{19}$ As conventional wisdom of SSR research points out, deviating from a genuine bottom-up community centric approach (over the state centric approach) is one example of this. Deviating from the bottom-up approach means inviting room for rejection, disrespect, co-optation and marginalisation or even manipulation of the security needs of the (marginalised) communities by the powerful local actors. Instead, norm hybridisation is a notable outcome of SSR assistance. ${ }^{20}$ Significant differences in norm trajectories between the EU and third countries, suspicion and a lack of local - elite buy-in to EU norms are some of the variables that could (partially) explain norm hybridisation. ${ }^{21}$ Norm hybridisation raises doubts about the EU's ability to implement new norms via SSR reforms in different cultural contexts, and within a usual short two to three year programme cycle. $^{22}$ Moreover, the recent approach of 'principled-pragmatism', has raised a new critique that the EU is back-peddling on its normative commitments, privileging its own security, neighbourhood and hard power, over democratisation. ${ }^{23}$

Against this background, this paper questions the EU's normative actorness via SSR programmes, and in particular, how key EU norms such as inclusivity, local ownership and gender equality are operationalised via SSR in Mali through the EUCAP Sahel-Mali mission. The paper analyses two stages of the EUCAP Sahel mission- planning and implementation, and two key activities of the mission training/capacity building and outreach.

\section{The EU's case for SSR in Mali}

Mali is one of the largest countries in Africa, located in the south of the Sahara. It has a population of $17,994,837$ inhabitants, of which $49.97 \%$ are women. ${ }^{24}$ In addition, a large proportion of persons (66.2\%) are under the age of 25 years. Economically, it is one of the poorest countries in the world. Mali takes the 179th place in the Human Development Index (2015) despite being the 'donor darling' in Africa. ${ }^{25}$ The complex and ever deepening security crisis experienced by Mali since 2012 is a manifestation of combination of economic, political and other governance deficits. The deteriorating security conditions are alluded to ongoing contestations between various armed groups for power and territorial control and the state's struggles against the increase in non-state armed groups. Various alliances formed between local Jihadist groups and Al-Qaeda, and organisations supported by Arab countries are blamed for Mali's worsening security crisis. At the beginning, the security crisis was largely limited to the remote areas where the

\footnotetext{
${ }^{19}$ S.Panebianco, 'The constraints to EU action as a 'norm entrepreneur' in the Mediterranean, paper presented at the ECPR Joint Sessions of Workshops themed New Roles for the European Union in International Politics (2004).

${ }^{20}$ U.C.Schroeder, F Chappuis and D.Kocak,'Security Sector Reform and the Emergence of Hybrid Security Governance', International Peacekeeping, 21, no.2 (2014):217.

${ }^{21}$ U.C.Schroeder and F.Chappuis 'New Perspectives on Security Sector Reform: The Role of Local Agency and Domestic Politics', International Peacekeeping, 21 (2): 133,148 (2014):137.

${ }^{22}$ Jayasundara-Smits (2015).

${ }^{23}$ Biscop (2016):92.

${ }^{24}$ World Bank 2016 figures at: https://data.worldbank.org/country/mali.

${ }^{25}$ I.Bergamaschi 'The Fall of a Donor Darling: The Role of Aid in Mali's Crisis', Journal of Modern African Studies, 52, no.3 (2014):347-378.
} 
state was starkly absent. Today, it is rapidly spreading to the capital and other urban areas. Initially, with the help of the French military action (Operation Serval $^{26}$ ), the Malian state was able to recapture some of the territories lost in the North (Gao, Timbuktu and Kidal) from the armed rebel groups (i.e. Malian Islamic movement- Ançar Dine). Nevertheless, to date, the overall security situation remains critical. ${ }^{27}$ These worsening security conditions demand major reforms to the Malian state's security apparatus as well as finding effective governance arrangements to address the underlying complex and multiple causes of the multiple crises hit by Mali.

\section{EUCAP Sahel-Mali mission: scope and functions}

The EU has long been a key development donor to Mali. ${ }^{28}$ However, under the heightened security crisis (since 2012), the EU began to increase assistance via the Comprehensive Regional Approach (2013) and Action Plan (2015) for the Sahel region by interlinking security, development and governance. ${ }^{29}$

In 2015, the EU established EUCAP Sahel-Mali as a civilian support mission, in addition to the European Union Training Mission (EUTM) that had been operational since February 2013. The main mandate of the EUCAP Sahel mission was to provide strategic advice and training to the three Malian internal security forces, i.e. the police, the Gendarmerie and the National Guard and to the relevant ministries, ${ }^{30}$ with the perspective of 'modernising' the Malian security sector. The EUCAP advisors are assigned to help their Malian counterparts to improve their national strategy for human resources, to modernise management practices and control of their services, and with the successfully recruitment of new staff within the Police, the Gendarmerie and the National Guard. As one could note, these activities are concerns with technical capacity building in the security sector. Mission's other related activities such as developing a human resources database, an employment policy and staff management database, a baseline for staffing, a skills-based staff recruitment policy, operational management methods to help restore hierarchical links, audit and inspection units within the general forces inspectorate, are targeting nothing other than bureaucratic uniformity and the functional imperative. Worryingly, the second phase of the mission (extended till 2019) shows increased focus on functional imperative and sliding away from the normative commitments. The newly introduced activities of strengthening the internal security forces' capacity to fight against terrorism and organised crime and

\footnotetext{
${ }^{26}$ This mission was undertaken by France in January 2013 following the United Nations Security Council Resolution 2085 in December 2012 and an official request from the Malian interim government for French assistance (United Nations Security Council, 'Security Council Press Statement on Mali' (2013).

${ }^{27}$ UN Security Council Press Statement 6 October 2017, https://www.un.org/press/en/2017/sc13019.doc.htm.

${ }^{28} \mathrm{~J}$. Carlsson, G.Somolekae and N. Van de Walle. Foreign Aid in Africa: Learning from Country Experiences, Nordiska Africinstutet, Uppsala (1997):145.

${ }^{29}$ Rapid launch of three SSR specific missions - EUTM, EUCAP Niger Sahel and EUCAP Sahel mission is seen as part of the EU's instrumental response to the Malian security crisis, which is intertwined with the EU's own security dilemma and the need for combatting combined effects of the humanitarian catastrophe, security challenges and the risk of large numbers of refugees coming to the EU. R.Gowan, 'Bordering On Crisis: Europe, Africa, and A New Approach to Crisis Management', Brief Policy, European Council on Foreign Relations (2017).

${ }^{30}$ EEAS (June 2016).
} 
supporting Mali in managing migration flows and border management ${ }^{31}$ provide evidence to this effect. These two specific activities are built on the logic of 'securitisation' thus enabling to by-pass the established norms and the rules. ${ }^{32}$ However, given the EU's overall approach to SSR, still one could assume all these activities to be undertaken, respecting the EU's normative principles underlying SSR. Yet, given the EU's recent eagerness to pursue a principled-pragmatic approach to crisis intervention as announced in its Global Strategy on Foreign and Security Policy (2016), pragmatism taking a precedence over the 'principled' is forewarned too. $^{33}$

As illustrated above, the overall mission is increasingly lacking in the balance between the functional and the normative imperative. This seems to be the case especially in the background of worsening security conditions in the Sahel region emanating from terrorism and increased irregular migration to Europe (least, according to the EU's interpretation). Given the complexity, enormity and pervasiveness of these challenges which the EU mission continued to grapple with, to an extent, one could understand the EU's inclination towards pragmatism. However, the long-term effects of EU's current approach in realising its normative commitments are a valid concern. Therefore, it is pertinent to find out what the EU does/ could do to operationalise SSR specific norms - inclusivity and local ownership in mission planning, implementation and evaluation and through its' everyday activities. In the following section, we analyse to what extent the mission planning was undertaken respecting these two norms, the challenges faced in doing so and the long and short term effects of (non) realisation.

\section{Mission planning: inclusions-exclusions and implications for norm (non) realisation}

The planning process of the EUCAP mission was undertaken respecting the principle of inclusivity. ${ }^{34}$ The overall goals and the content of the mission was decided in-line with the National Strategies (Plan pour la reliance durable du Mali-PRED2013-2014) presented by the Malian state authorities. ${ }^{35}$ The EU's planning process was aimed at maximising the local engagement and ownership of the reform process, as well as eventually holding the Malian counterparts responsible for the mission's outcomes. However, there are a number of issues identified in relation to the degree of ownership and inclusivity of the EU's approach during mission planning. The exclusion of some local actors meant the planning process

\footnotetext{
${ }^{31} \mathrm{EU}$ Official website of the mission https://eucap-sahel-mali.eu/.

${ }^{32}$ B.Buzan, O.Waever and J.De Wilde.Security, A New Framework for Analysis (London: Lynne Rienner Publishers Inc. (1998):23.

${ }^{33}$ Use of EU's new Partnership Framework with Third Countries (EC 2016) is an alarming development where pragmatism is looming larger over the normative in EU policy and practice. This framework is currently used to strike 1-1 deals with a number of rough regimes such as Ethiopia, Turkey, Sudan and Libya to address the EU migration crisis. Although EU has been able significantly reduce the number of migrants arriving at their borders, the deal has come under heavy criticism for sacrificing the international norms and principles in achieving these results.

${ }^{34}$ DCAF and FBF, Country Case Studies to Inform the EU-wide Strategic Framework for Supporting SSR: Findings from Mali, DRC AND Ukraine, Final Report. Geneva, (March 2016):21.

${ }^{35}$ M.Djiré, D.Sow, K.Gakou and B.Camara, Assessing the EU's conflict prevention and peacebuilding interventions in Mali. Bamako: Université des Sciences Juridiques et Politiques de Bamako (2016):7.
} 
fell short on its aim of inclusivity. Although the planning documents mention involving civil society in planning, its role is limited to a supporting and a contributory actor to the mission, and it was excluded in terms of subjectivities ideas, norms and visions. Furthermore, the non-involvement of actors from the Northern part of the country during the consultation process ${ }^{36}$ is notable. Such exclusions can be counterproductive inasmuch as they create the risk of competing and overlapping types of security governance arrangements at local level, which are based on different religious and family structures. ${ }^{37}$ Although largely informal, these security arrangements are found to be effective. The role they play in providing security in the remote areas-where the state is absent appear vital. ${ }^{38}$ Exclusion of these actors and the favouring of a top-down model based on EU standards marginalise and reject the local episteme of security and make local communities passive recipients or subordinates of the external model. Furthermore, the process followed by the EU-represented marginalisation of the northern population, already a source of grievance among people in this part of the country. One fear is that this could contribute to escalate the current security crisis as the marginalised northern actors resort to violence to express and draw attention to their grievances. It also increases the risk that following a traditional 'train and equip' approach could stimulate the competition for power and hegemony between different elite groups as they attempt to capture the new security institutions.

The EU also compromised its own norms by co-opting, by pushing its own security agenda above local demands and needs. Furthermore, it was claimed that the EU pressured local elites to comply with its own priorities. ${ }^{39}$ The new mission goals of strengthening of the internal security forces' capacity in the fight against terrorism and organised crime, support for managing migration flows and border management ${ }^{40}$ not only reflected a privileging of the EU's security interests, which is at odds with the norm of local ownership. The EU was also criticised for concluding 'deals' with the local elites, ${ }^{41}$ which resulted in strengthening the repressive powers of the local elites and exacerbating governance deficits. Thus, new security arrangements that emerge through such a bargaining process run the risk of establishing 'ceremonial' security institutions which lack any value proposition imbued in them. ${ }^{42}$

\footnotetext{
${ }^{36}$ Nevertheless the Algeria brokered a peace deal 'Agreement for Peace and Reconciliation in Mali, resulting from the Algiers Process" (also known as the 'Bamako Agreement') signed in 2015 included an alliance of Tuareg-led rebels and the Malian State representatives. The implementation of the peace process is far behind schedule and its achievements so far are very little A.Boutellis and Marie-Joëlle Zahar, ' Process in Search of Peace: Lessons from the Inter-Malian Agreement,' New York: International Peace Institute (2017):2.

${ }^{37} \mathrm{~J}$. Aulin and C.Divin, 'Towards Local Ownership of International Interventions in Mali', Policy Note, Issue 1, Global Partnership for the Prevention of Armed Conflict, The Hague (2017).

${ }^{38}$ Aulin and Divin (2017).

${ }^{39}$ ibid.

${ }^{40}$ EC, PRESS RELEASE 8/17 11/01/2017 EUCAP Sahel Mali: mission extended for two years, $€ 29.7$ million budget adopted.

${ }^{41}$ M.Barnett and C.Zürcher, 'The Peacebuilders Contract: How External State-building Reinforces Weak Statehood', in The Dilemmas of Statebuilding: Confronting the Contradictions of Post-war Peace Operations, eds. R. Paris and T. Sisk (2009): 13-52.

${ }^{42}$ Ibid:39.
} 


\section{Mission execution: training and capacity building}

The next section looks at how inclusivity was encouraged and/or prevented by the mission as part of its training and capacity building activities.

Training and capacity development are the main objectives of the EUCAP Sahel mission. In order to reach these goals, the mission uses a training and capacity building curriculum. As the mission website ${ }^{43}$ states, the EUCAP Sahel training and capacity building activities are developed 'jointly with the United Nations Multidimensional Integrated Stabilisation Mission in Mali (MINUSMA) and the EUTM Mali military training mission in order to optimise support for the Malian state'. This approach raises many issues. First, it implies limitations in a training curriculum intended for civilian purposes, conducted by a military mission. Second, such an approach prioritises the superiority of military's knowledge and values over that of the civilian. On one hand, this approach may help to socialise the Malian security forces in terms of the international system, doctrines and the international norms. At the same time, it could distance them from local communities, their realities and assessments of security threats at everyday level. The latter is already reflected in the content of the training provided. The EUCAP training curriculum covers a large number of technical subjects, such as management and command, professional ethics, intelligence techniques, professional intervention, criminal policing, counter-terrorism and public order. ${ }^{44}$ The training curriculum gives little attention to norm-related topics. At present, they are limited to training on the topics 'Human Rights and Gender. ${ }^{45}$

The EUCAP training programmes target the staff at senior and the intermediate levels. Each selected staff member receives $100 \mathrm{~h}$ of individual training on all topics, over a period of 4 weeks. So far, about 1600 security personals have undergone the programme. The training programme also has a training of trainers (TOT) component. The goal of TOT is to promote local ownership of the training programme. With the support of the EU training advisers, the participants are selected by the commanders of the Malian three internal civilian forces. Due to the culture of 'following orders' in the armed forces, undergoing the EUCAP training programme appears obligatory than voluntary. The obligatory character of the training thus raises issues of varying degrees of interest and commitment to different subject matters by the participants. Without giving a chance to voluntarily enlist, there is no way of knowing participants' underlying motivations for taking part in the training programme. It may well be the case that the seriously impoverished Malian soldiers, finding the components of weapons and technical training more attractive over the normative part. Previous incidents of mass dissertation by several US-trained battalions (including the 2012 coup leader Captain Amadou Sanogo) upon completing a US-led anti-terror training programme, the trained soldiers eventually joining the National Movement for the Liberation of Azawad (MNLA) and committing mass atrocities against the Tuaregs and Arabs illustrate negative examples of the related

\footnotetext{
${ }^{43}$ EUCAP official website https://eucap-sahel-mali.eu/.

${ }^{44}$ EUCAP official website https://eucap-sahel-mali.eu/.

${ }^{45}$ In terms of offering training on gender and Human rights, Mali paints a crowded scenario, where many international, regional and civil society organisations are conducting such training courses for the Malian security forces, and the civil society organisations (i.e. MINUSMA, UN Women and UNFPA, Beyond Peace) .
} 
motivational dimension. ${ }^{46}$ Recalling this particular incident, Prof. Goita shared, 'As far as I'm aware, more than 80 Malian soldiers deserted after the training course, taking their weapons and baggage with them'. 4

The criteria applied for selecting participants also point to a compromise of the normative principles of local ownership and inclusivity. As the mission documents reveal, themed-level and higher officials are the main target groups of the trainings. From the point of view of the EU and of the Malian authorities, there are justifiable reasons for this choice. For instance, targeting higher level officials is important for buyin to the programme, to counter internal resistance and create conditions for local ownership and responsibility. ${ }^{48}$ Excluding higher officials creates mal-functioning security sector institutions, and instances of 'loose coupling' between what is formal and what is the actual day-to-day practice. ${ }^{49}$ Having a more inclusive enrolment strategy that targets the security actors at the bottom of the hierarchy is important, while excluding front line cadres who interact with local communities is a missed opportunity to learn from their everyday experiences in understanding and addressing local security needs. In this way, the mission lost an opportunity to integrate their experience and (tacit) inputs for designing the training programme and making it 'relevant' in addressing complex real life security challenges. ${ }^{50}$ As Gordon argued, including the security actors from the bottom of the hierarchy is useful for building genuine local ownership, addressing local needs and increasing trust, confidence and legitimacy of security institutions. ${ }^{51}$

As mentioned before, there was an imbalance between the technical and normative parts of the EUCAP training curriculum. Ninety-five per cent of the overall curriculum consists of technical subjects. Only two topics (Human Rights and Gender) cover normative aspects. Therefore, for the Malian soldiers who take part in the training programme, the marginal attention given to the norm-related subjects in the curriculum may mean superiority of technical over the normative. It could also mean EU losing out of an important opportunity in achieving its combined functional-normative values of preparing well-trained soldiers who also fight respecting human rights, avoiding unlawful practices, not engaging in torture and rape. Also, the content of the two norm-related topics deals with the legal backgrounds of these subjects (International Humanitarian Law and United Nations Frameworks for Gender Equality). ${ }^{52}$ In addition, even the trainers who delivered the normative parts of the

\footnotetext{
${ }^{46}$ P.Hatcher, 'French general urges EU to equip "impoverished" Mali army', Reuters (20February 2013).

${ }^{47}$ K.Gänsler, EU military training in Mali (2013), at: http://p.dw.com/p/17Qrr .

${ }^{48}$ Jayasundara-Smits and L.Schirch (2015):18.

${ }^{49}$ Schroeder and Kocak:217.

${ }^{50}$ Author's previous personal experiences in conducting Human Rights training programmes (2005-2007) for Sri Lanka's military and the police by separating the higher officers from the soldiers indicates several gaps. On one hand, separate training was an effective strategy to foster an environment for full participation of the each group of participants without prejudice and by overcoming the 'hierarchy' in these establishments. On the other hand, it was also a lost opportunity in fostering collaborative partnerships between different rungs and in developing empathy to each other's roles and tasks.

${ }^{51}$ Schroeder and Chappuis, 'New Perspectives on Security Sector Reform:', 1.

${ }^{52}$ This shows similarity with the reflections from the ISSAT, the main training provider for the EUTAM training mission on International Humanitarian Law and Human Rights. As the project reflection paper notes, the design and the delivery of the military training curriculum taking priority over the Human rights trainings and the ratio of military versus Human rights trainers was 185:1 (http://issat.dcaf.ch/Learn/SSR-in-Practice/Countries-Regions/Mali?view= resources).
} 
curriculum expressed their deep dissatisfaction with the overbearing nature of the combat and intelligence-related subjects in the curriculum. They are also not satisfied with the format of the training delivery that compartmentalises the normative and the technical subjects. ${ }^{53}$ The strict separation between the technical and normative subjects is also problematic as it misses the simultaneous interactive dynamics between the norms and the functions. Against the general passive learning culture in Mali, achieving the normative goals with this particular format is challenging. As one EU trainer (technical) who conducted a practical training session on police forensic investigation exercise commented, despite their enthusiasm to learn, the Malian participants are spectators than active participants. ${ }^{54}$

With regard to inclusivity, as a whole, the EUCAP training and its related technical and normative components were mainly delivered by the EU member states and their northern civil society counterparts. For instance, Human Rights training was mostly delivered by a French civil society organisation 'Beyond Peace' ${ }^{55}$ According to the recent documents, the $\mathrm{HR}$ training is also delivered in partnership with EUTM, MINUSMA and international human rights organisations: ICRC and UN Women. ${ }^{56}$ The choice of northern civil society organisations in delivering the normative parts of the curriculum is noteworthy here. At the outset, the heavy involvement of the northern CSOs signals out a cultural connotation. As Lederach reminds us, training is one key element of capacity building and it is about selling 'social' knowledge. ${ }^{57}$ 'Selling social knowledge' requires concientisation- awareness of self in context and promoting both personal and social transformation in the participants. ${ }^{58}$ Therefore, when crossing cultural boundaries in training, it is crucial to deploy trainers from a mixture of cultural backgrounds. ${ }^{59}$ Solely assigning the northern organisations to deliver, especially the normative content of the training (or in other words 'selling cultural knowledge') not only excludes local actors, it also means exclusion of different knowledge traditions and epistemes. By side-lining the local actors- hence local norms and cultures and practices - the mission's training activities seemed to have missed out on an important opportunity for dialogue and (re) negotiation or co-invention of new norms that are acceptable, meaningful and implementable in the local context.

\section{Outreach activities: the matter of gender}

In this section, we analyse outreach as one of the key activities undertaken by the EUCAP Sahel-Mali mission. Outreach activities provide an important public space for the EU to demonstrate its commitment and consistent application of its own norms in everyday activities of the mission, thus demonstrating its normative actorness. Outreach activities of the mission are used here to illustrate how and to what extend the EU's normative actorness is achieved/compromised through practice of gender equality - a norm that is being repeatedly affirmed in EU policy

\footnotetext{
${ }^{53}$ ibid.

${ }^{54}$ European Gendarmerie Force, 'A look inside EUCAP Sahel Mali' at: http://www.eurogendfor.org.

${ }^{55}$ ISSAT .

${ }^{56}$ DCAF and FBF (2016):24.

${ }^{57}$ J.P.Lederach, Preparing for Peace: Conflict Transformation Across Cultures, Syracuse University press. (1996):6.

${ }^{58}$ Lederach (1996): 19.

${ }^{59}$ Lederach (1996):23.
} 
documents. $^{60}$ Gender equality is integral to local ownership and inclusivity, because it cuts across all the norms underpinning SSR (human rights, good governance, and democracy) and sits in every intersection of all social relationships, relations of power. ${ }^{61}$ Gender equality is an important normative criterion of measuring the success of SSR programmes. It is not because men and women experience security differently, but also because the security institutions must be representative and equally responsive to the needs of both men and women and owned by both men and women. ${ }^{62}$

However, gender equality is not an easily transferable norm across cultures. ${ }^{63}$ In order to realise gender equality, the EUCAP mission needed to think 'outside the box'. Outreach provides an opportunity for tapping into neglected or seemingly invisible 'everyday spaces' to communicate/practice norms regularly. It can be an important and subtle means for debating, assessing, reflecting and renegotiating norms in the local context.

Using the mission's publicly available outreach documents ${ }^{64}$ (which focuses on training and capacity building) and by applying the WOS perspective with a focus on the inclusions and exclusions, presences and absences dimensions, ${ }^{65}$ this section throws light on how gender equality is being practiced by the mission. A cursory look at the mission's outreach materials suggests however that it lacks sensitivity towards gender equality as a key normative principle. Instead, these documents indicate a reinforcement of gender inequality within the mission, in the capacity building programme and in Malian society. Over representation of men, compared to women in mission's public documents is one of the key issues identified. For instance, at least $90 \%$ of the images used in the mission's periodical newsletter - 'La Gazelle (Journal d'information de la Mission EUCAP Sahel-Mali), the foreign male mission staff and their local male counterparts are made hyper visible. These images feed into the existing social stereotypes of 'dominant men'. Furthermore, their presences in the outreach materials are established using images taken mostly during weapons training sessions. Yet again, these images reinforce another social stereotype of 'violent men'. These images do not remain as 'just images', but are being continually mediated by the local cultural and political contexts and by existing relations of power in the Malian society, and hence they have serious normative implications on the Malian society. Furthermore, the absence of women in the outreach materials also reproduces the established stereotypes of women as innocent, vulnerable, marginalised, passive and subjects (victims) of man's violence. By so doing, these materials contribute in making the agency of Malian women invisible. Malian women's

\footnotetext{
${ }^{60}$ M.Villellas, Pamela Urrutia, Ana Villellas, Vicenç Fisas, Gender in EU Conflict Prevention and Peacebuilding Policy and Practice, Escola de Cultura de Pau,Barcelona (2016):15. This is also endorsed by the landmark UN Security Council Resolution 2151 on SSR.

${ }^{61}$ Gordon, Welch \& Roos, 'Security Sector Reform and the Paradoxical Tension', 4.

${ }^{62}$ L.Schirch (with Mancini-Griffoli, Deborah), Local Ownership in Security: Case Studies of Peacebuilding Approaches. The Hague: Alliance for Peacebuilding, GPPAC, Kroc Institute (2015):8.

${ }^{63}$ This is also the case with other norms underpinning SSR such as democracy, good governance, human rights.

${ }^{64}$ Mission website contains other documents such as factsheets, guidelines with dealing with victims of violence against women and girls and the handbooks on Criminal Code, on Border Management and on Violence against women and girls.

${ }^{65}$ Visual analysis of the newsletter was conducted using media and visual analysis tools of Framing and Focalisation. See C.B.Schwalbe, 'Remembering our Shared Past: Visually Framing the Iraq

War on US News Websites', Journal of Computer-Mediated Communication, 12, no.1 (2006):264-289; M. Meijer, 'Countering textual violence: On the critique of representation and the importance of teaching its methods', Women's studies international forum, Elsevier (1993):367-378.

${ }^{66}$ There are four newsletters issues so far, Issue no.1 (14 January 2016), no:2 (May 2016), and no.3 (January 2017) and no.4 (May 2017).
} 
presence in the outreach material is more prominent on topics related to civil society, human rights and gender-related activities. These images thus reproduce new societal stereotypes of women (particularly in places Western interventions are taking place), as accomplices of the west's intrusive liberal peace project. Regular presences of white-western women as 'training providers' in these materials also recast what Paris cited as 'mission civilisatrice'. ${ }^{67}$ Portraying white-western women in superior positions recast black-local men (and women) as powerless, uneducated, immature and passive subjects. These numerous visibilities and invisibilities enacted through the images in the mission's outreach materials recast the societal racegender power relations as well. ${ }^{68}$ Taken together, these numerous presences and absences and particular instances of presences and absences compromise the principles of inclusiveness, local ownership and gender norms.

\section{Conclusion}

Applying the WOS approach, this paper has shown how two key SSR norms of local ownership and inclusivity (inclusive of gender equality) presented operational challenges for the EUCAP Sahel-Mali mission. These challenges were identified at two levels: first at the level of overall Malian context (broad) and second at the mission's operational level (specific). Realising and internalising norms was found to be more difficult against the background of a worsening security crisis in Mali and in the Sahel region which contributed to distracting the EU and their local partners from the normative goals of SSR. This situation is further encouraged by the EU's 'principled-pragmatic' approach to crisis intervention, reflected in the activities of the mission's second mandate.

From the perspective of WOS, viewing the mission through the prism of the vertical (inclusiveness of actors) and the horizontal axes (practices) this paper captured the overtly functional- instrumental nature of the EUCAP Sahel-Mali mission. The mission's main objective - training a third of the staff of the internal security forces in over four weeks, underlines the mission's preference for applying a short term, top-down functional approach rather than a longer term normative governance-development approach. This was further demonstrated in the activities of the second phase of the mission that largely focus on counter-terrorism and border management. These activities show how the mission prioritises EU security interests over local security considerations, suggesting both a lack of inclusivity and local ownership and exclusion and marginalisation of local actors during the planning processes (and even co-optation and manipulation of some of the key actors) who have important stakes in the Malian security scenario.

By delving into the mission's training activities and modalities of their delivery, this paper traced various instances of inclusions, exclusions and marginalisations of actors and the norms. The imbalance (between normative and functional subjects) in the training curriculum and the mission's inability to itself demonstrate its own norms of inclusivity and gender equality when it came to building training teams and the selection of participants was

\footnotetext{
${ }^{67}$ R.Paris, 'International Peacebuilding and the "Mission Civilisatrice"',.. Review of International Studies, 28, no.4 (2002):638.

${ }^{68}$ This finding also echoes Spivak's observations on how the 'white' Western wo/man gender expert takes the role of saving 'brown/local' wo/men victims (Op Cit., in Kunz (2014):610.
} 
significant. Although improved gender sensitivity is suggested by normative considerations, including more women in missions and utilising their agency has also been seen to increase the functional effectiveness in other cases of SSR missions. These examples show how women can help gain trust and acceptance more easily from the local communities and act as effective carrier of normative messages. $^{69}$

The analysis of the mission's public outreach documents suggests how the mission could be an effective vehicle for norm diffusion by focusing on how information is shared rather than the kind of information provided. A WOS approach suggests that the mission could have pursued a more inclusive approach by considering segments such as the Northern populations, and women in the training and outreach activities. In addition, by reviewing their training and outreach activities against local practices and by aligning more closely with best practices on gender at international level, and by integrating national plans and priorities on issues such as inclusivity, use of the horizontal WOS axis could have improved the mission's normative focus.

Overall, these findings suggest the need to acknowledge and engage more deeply with the normative implications and the underlying political dimension and context of the mission. A deeper level of political engagement is crucial if the mission is to make an impact on Malian society and its social-political institutions. By delving deeper into the mission specific activities (planning and implementation-training and outreach) this paper was also able to identify a number of issues in operationalising and realising the EU's own norms, which in turn challenge the EU's overall credibility as a normative actor. However the mission specific challenges are easier to address by adjusting everyday activities, and here, a WOS perspective, would highlight opportunities to counter the incidence of exclusions, invisibilities and marginalisation in terms of actors and norms. A WOS approach could strengthen the rhetorical commitments and restore the EU's diminishing reputation as a normative actor.

\section{Abbreviations}

$\begin{array}{ll}\text { CSDP } & \text { - Common Security and Defence Policy } \\ \text { CSO } & \text { - Civil Society Organisation } \\ \text { EU } & \text { - European Union } \\ \text { EUCAP } & \text { - Sahel Mali - European Capability Building Mission Sahel Mali } \\ \text { EUTM } & \text { - European Union Training Mission } \\ \text { ICRC } & - \text { The International Committee of the Red Cross } \\ \text { MINUSMA } & \text { - United Nations Multidimensional Integrated Stabilisation Mission in } \\ & \text { Mali } \\ \text { MNLA } & - \text { National Movement for the Liberation of Azwad } \\ \text { OECD } & - \text { Organisation for Economic Co-operation and Development } \\ \text { SSR } & - \text { Security Sector Reform } \\ \text { TOT } & - \text { Training of Trainers } \\ \text { WOS } & - \text { Whole of Society }\end{array}$

\footnotetext{
${ }^{69} \mathrm{~J} .0$ 'Neill and J. Vary, 'Allies and Assets: Strengthening DDR and SSR through Women's Inclusion' in Monopoly of Force: The Nexus of DDR and SSR, edds. Melanne A. Civic and Michael Miklaucic (The National DEFENCE University, Washington D.C 2011):94; S.Jayasundara-Smits, Civil-Military Synergy at Operational Level in EU External Action, WOSCAP-EU, Global Partnership for the Prevention of Armed Conflict (GPPAC), The Hague (2016):22.
} 


\section{Acknowledgment}

Author would like to thank the anonymous peer-reviewers for their helpful comments, Dr. Vesna Bojičić-Dželilović and Dr.Mary Martin at LSE for their advise and critical comments during various stages of writing of this article.

\section{Disclosure statement}

No potential conflict of interest was reported by the author.

\section{Funding}

This work was supported by the European Union's Horizon 2020 Research and Innovation Programme [grant number 653866.

\section{Notes on contributor}

Shyamika Jayasundara-Smits is an associate researcher with the International Institute of Social Studies (ISS) of Erasmus University Rotterdam, The Netherlands. She also teaches in Governance and Conflict in ISS's MA Degree Programme in Development Studies. She holds a PhD in Development Studies from ISS, Erasmus University Rotterdam and MA in Conflict Transformation and Peacebuilding from Eastern Mennonite University, Virginia, USA. She is a former Fulbright Fellow.

\section{ORCID}

Shyamika Jayasundara-Smits (D) http://orcid.org/0000-0002-1022-269X 